\title{
CLINICAL DISORDERS \\ OF MEMBRANE \\ TRANSPORT PROCESSES
}




\section{CLINICAL DISORDERS OF MEMBRANE TRANSPORT PROCESSES}

Edited by

Thomas E. Andreoli, M.D. University of Texas Medical School Houston, Texas

Joseph F. Hoffman, Ph.D. Yale University School of Medicine New Haven, Connecticut

Darrell D. Fanestil, M.D.

University of California, San Diego La Jolla, California

and

Stanley G. Schultz, M.D. University of Texas Medical School Houston Texas 


\section{Library of Congress Cataloging in Publication Data}

Physiology of membrane disorders. Selections.

Clinical disorders of membrane transport processes.

"This volume is a reprint with minor modifications of part VI of Physiology of membrane disorders, second edition, published by Plenum Medical Book Company in 1986"-T.p. verso.

Includes bibliographies and index.

1. Membrane disorders. I. Andreoli, Thomas E., 1935- . II. Title. [DNLM: 1. Biological Transport. 2. Membranes-physiopathology. 3. Metabolic Diseases. QS 532.5.M3 P5782c]

RB113.P492 1987

ISBN-13: 978-0-306-42699-5

DOI: $10.1007 / 978-1-4684-1286-4$

This volume is a reprint with minor modifications of Part VI of

Physiology of Membrane Disorders, Second Edition, published by Plenum Medical Book Company in 1986.

(C) 1986, 1987 Plenum Publishing Corporation

233 Spring Street, New York, N.Y. 10013

Plenum Medical Book Company is an imprint of Plenum Publishing Corporation

All rights reserved

No part of this book may be reproduced, stored in a retrieval system, or transmitted in any form or by any means, electronic, mechanical, photocopying, microfilming, recording, or otherwise, without written permission from the Publisher 


\section{Contributors}

THOMAS E. ANDREOLI, M.D.

Edward Randall III Professor and Chairman

Department of Internal Medicine

Professor of Physiology and Cell Biology

University of Texas Medical School

Houston, Texas 77225

STANLEY H. APPEL, M.D.

Professor and Chairman

Program in Neuroscience

Department of Neurology

Baylor College of Medicine

Houston, Texas 77030

LOUIS V. AVIOL, M.D.

Professor of Medicine

Department of Medicine

Washington University School of Medicine at The Jewish Hospital of St. Louis

St. Louis, Missouri 63110

LEE R. BERKOWITZ, M.D.

Department of Medicine

University of North Carolina

School of Medicine

Chapel Hill, North Carolina 27514

STANLEY J. BIRGE, M.D.

Associate Professor of Medicine

Department of Medicine

Washington University School of Medicine at The Jewish Hospital of St. Louis

St. Louis, Missouri 63110

ROLAND C. BLANTZ, M.D.

Professor of Medicine

Department of Medicine

University of California, San Diego

School of Medicine

La Jolla, California 92093

Chief of Nephrology

Veterans Administration Medical Center

San Diego, California 92161

JOSEPH V. BONVENTRE, M.D., PH.D.

Assistant Professor of Medicine

Department of Preventive Medicine

and Clinical Epidemiology

Massachusetts General Hospital

Department of Medicine
Harvard Medical School and Massachusetts General Hospital

Boston, Massachusetts 02114

JOSEPH Y. CHEUNG, M.D.

Research Fellow in Medicine

Department of Preventive Medicine and Clinical Epidemiology

Massachusetts General Hospital

Department of Medicine

Harvard Medical School and

Massachusetts General Hospital

Boston, Massachusetts 02114

R. MICHAEL CULPEPPER, M.D.

Assistant Professor of Medicine

Division of Nephrology

University of Texas Medical School

Houston, Texas 77225

RALPH A. DEFRONZO, M.D.

Associate Professor of Medicine

Department of Medicine

Yale University School of Medicine

New Haven, Connecticut 06510

JOHN M. DIETSCHY, M.D.

Professor of Medicine

Department of Internal Medicine

Southwestern Medical School

University of Texas Health Science Center

Dallas, Texas 75235

ROBERT F. GILMOUR, JR., PH.D.

Assistant Professor of Pharmacology

and Medicine

Krannert Institute of Cardiology

Departments of Medicine and Pharmacology

Indiana University School of Medicine

Indianapolis, Indiana 46223

\section{ALBERT M. GORDON, PH.D.}

Professor

Department of Physiology and Biophysics

University of Washington School of Medicine

Seattle, Washington 98195

STEVEN C. HEBERT, M.D.

Assistant Professor of Medicine

Division of Nephrology 
University of Texas Medical School

Houston, Texas 77225

Present address

Department of Internal Medicine Brigham and Women's Hospital

Boston, Massachusetts 02115

LEONARD R. JOHNSON, PH.D.

Professor of Physiology and Cell Biology Department of Physiology and Cell Biology

University of Texas Medical School

Houston, Texas 77225

ALEXANDER LEAF, M.D.

Professor of Medicine

Ridley Watts Professor of Preventive Medicine

Department of Preventive Medicine

and Clinical Epidemiology

Massachusetts General Hospital

Department of Medicine

Harvard Medical School and

Massachusetts General Hospital

Boston, Massachusetts 02114

ANTHONY D. C. MACKNIGHT, M.D., PH.D.

Department of Physiology

University of Otago Medical School

Dunedin, New Zealand

JOHN A. MANGOS, M.D.

Professor of Physiology and Pediatrics

Chairman, Department of Pediatrics

University of Texas Health Science Center

San Antonio, Texas 78284

JOSEPH PALMISANO, M.D.

Assistant Professor of Medicine

Division of Nephrology

Department of Medicine

University of Connecticut School of Medicine

Farmington, Connecticut 06032

JOHN C. PARKER, M.D.

Professor of Medicine

Department of Medicine

University of North Carolina

School of Medicine

Chapel Hill, North Carolina 27514

JUAN C. PELAYO, M.D.

Assistant Professor of Medicine

Department of Medicine

University of California, San Diego

School of Medicine

La Jolla, California 92093

Veterans Administration Medical Center

San Diego, California 92161

GORDON A. PLISHKER, PH.D.

Assistant Professor of Neurology

Program in Neuroscience

Department of Neurology

Baylor College of Medicine

Houston, Texas 77030
BENGT RIPPE, M.D.

Department of Physiology

University of South Alabama

College of Medicine

Mobile, Alabama 36688

ROBERT L. RUFF, M.D., PH.D.

Assistant Professor

Department of Neurology

Cleveland Veterans Administration Hospital and Case Western Reserve University

Cleveland, Ohio 44106

JERRY A. SCHNEIDER, M.D.

Professor of Pediatrics

Metabolic Diseases Division

Department of Pediatrics

University of California at San Diego

La Jolla, California 92093

JOSEPH D. SCHULMAN, M.D.

Director

Genetics and IVF Institute

Department of Obstetrics and Gynecology

Fairfax Hospital

Fairfax, Virginia 22031

PHILIP R. STEINMETZ, M.D.

Professor of Medicine

Chairman, Division of Nephrology

Department of Medicine

University of Connecticut School of Medicine

Farmington, Connecticut 06032

AUBREY E. TAYLOR, PH.D.

Professor and Chairman

Department of Physiology

University of South Alabama

College of Medicine

Mobile, Alabama 36688

SAMUEL O. THIER, M.D.

Professor and Chairman

Department of Medicine

Yale University School of Medicine

New Haven, Connecticut 06510

HENRIK WESTERGAARD, M.D.

Assistant Professor of Medicine

Department of Internal Medicine

Southwestern Medical School

University of Texas Health Science Center

Dallas, Texas 75235

DOUGLAS P. ZIPES, M.D.

Professor of Medicine

Director of Cardiovascular Research

Krannert Institute of Cardiology

Department of Medicine

Indiana University School of Medicine

Roudebush Veterans Administration

Medical Center

Indianapolis, Indiana 46223 


\section{Preface}

Clinical Disorders of Membrane Transport Processes is a softcover book containing a portion of Physiology of Membrane Disorders (Second Edition). The parent volume contains six major sections that deal with general aspects of the physiology of transport processes and specific aspects of transport processes in cells and in organized cellular systems, namely epithelia. This text contains the last section, which deals with the application of the physiology of transport processes to the understanding of clinical disorders.

We hope that this smaller volume will be helpful to individuals particularly interested in clinical derangements of membrane transport processes.

Thomas E. ANDREOLI JOSEPH F. HOFFMAN

DARRELL D. FANESTIL

Stanley G. Schultz 


\section{Preface to the Second Edition}

The second edition of Physiology of Membrane Disorders represents an extensive revision and a considerable expansion of the first edition. Yet the purpose of the second edition is identical to that of its predecessor, namely, to provide a rational analysis of membrane transport processes in individual membranes, cells, tissues, and organs, which in turn serves as a frame of reference for rationalizing disorders in which derangements of membrane transport processes play a cardinal role in the clinical expression of disease.

As in the first edition, this book is divided into a number of individual, but closely related, sections. Part V represents a new section where the problem of transport across epithelia is treated in some detail. Finally, Part VI, which analyzes clinical derangements, has been enlarged appreciably.

THE EDITORS 


\section{Contents}

CHAPTER 1: The Cellular Basis of Ischemic Acute Renal Failure

ALEXANDER LEAF, ANTHONY D. C. MACKNIGHT, JOSEPH Y. CHEUNG, and JOSEPH V. BONVENTRE

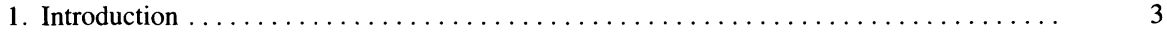

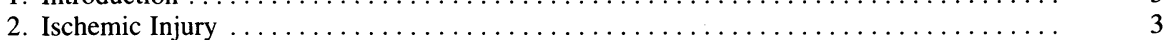

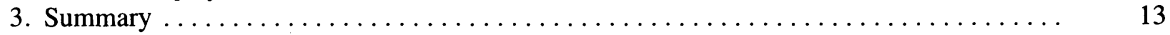

References $\ldots \ldots \ldots \ldots \ldots \ldots \ldots \ldots \ldots \ldots \ldots \ldots \ldots \ldots \ldots \ldots \ldots \ldots \ldots \ldots \ldots$

CHAPTER 2: Genetic Variants Affecting the Structure and Function of the Human Red Cell Membrane

JOHN C. PARKER and LEE R. BERKOWITZ

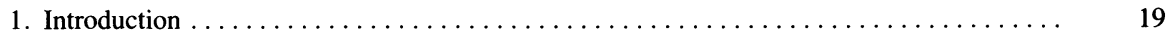

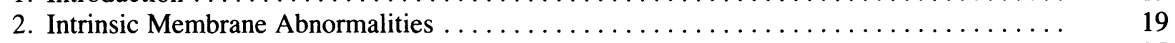

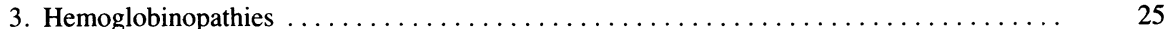

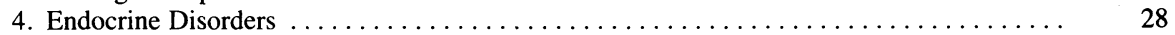

5. Manic-Depressive Disease $\ldots \ldots \ldots \ldots \ldots \ldots \ldots \ldots \ldots \ldots \ldots \ldots \ldots \ldots \ldots \ldots \ldots \ldots \ldots \ldots$

6. Essential Hypertension $\ldots \ldots \ldots \ldots \ldots \ldots \ldots \ldots \ldots \ldots \ldots \ldots \ldots \ldots \ldots \ldots \ldots \ldots \ldots \ldots$

7. Inherited Neuromuscular Disorders $\ldots \ldots \ldots \ldots \ldots \ldots \ldots \ldots \ldots \ldots \ldots \ldots \ldots \ldots \ldots \ldots \ldots$

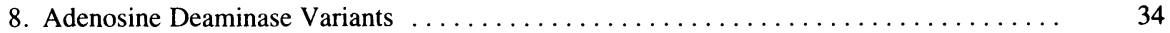

References $\ldots \ldots \ldots \ldots \ldots \ldots \ldots \ldots \ldots \ldots \ldots \ldots \ldots \ldots \ldots \ldots \ldots \ldots \ldots \ldots$

CHAPTER 3: Inherited Membrane Disorders of Muscle: Duchenne Muscular Dystrophy and Myotonic Muscular Dystrophy

GORDON A. PLISHKER and STANLEY H. APPEL

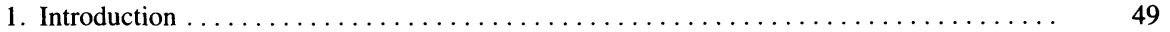

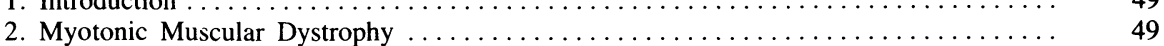

3. Duchenne Muscular Dystrophy $\ldots \ldots \ldots \ldots \ldots \ldots \ldots \ldots \ldots \ldots \ldots \ldots \ldots \ldots \ldots \ldots \ldots \ldots \ldots$

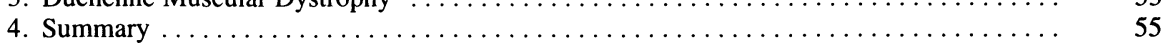

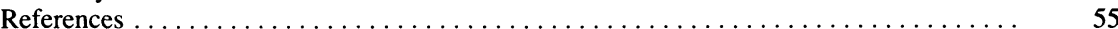

CHAPTER 4: Disorders of Muscle: The Periodic Paralyses ROBERT L. RUFF and ALBERT M. GORDON

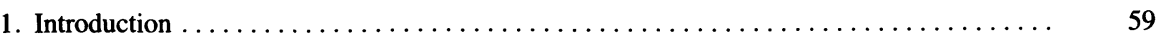

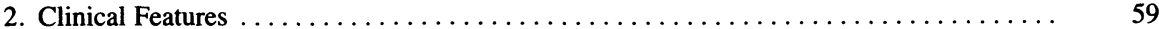

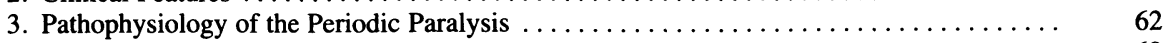

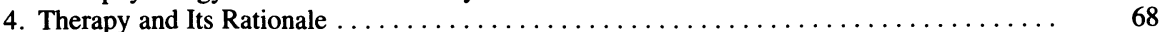

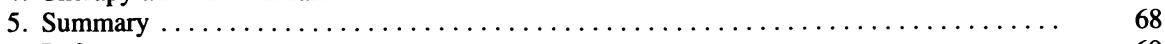

References $\ldots \ldots \ldots \ldots \ldots \ldots \ldots \ldots \ldots \ldots \ldots \ldots \ldots \ldots \ldots \ldots \ldots \ldots \ldots \ldots$ 
CHAPTER 5: Pathophysiology of Cardiac Arrhythmias

ROBERT F. GILMOUR, JR. and DOUGLAS P. ZIPES

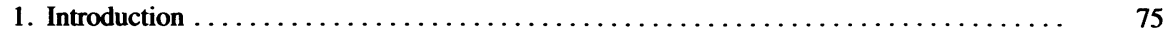

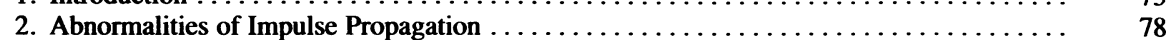

3. Interactions between Abnormal Impulse Formation and Propagation ............ 80

4. Electrophysiological Mechanisms Responsible for Clinically Occurring Arrhythmias .... 82

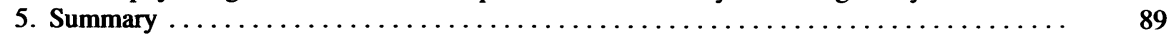

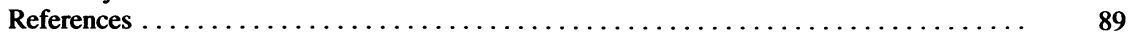

CHAPTER 6: Pathophysiology of Peptic Ulcer Disease LEONARD R. JOHNSON

1. Introduction . . . . . . .

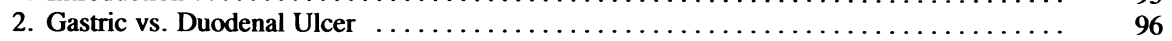

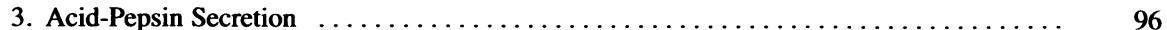

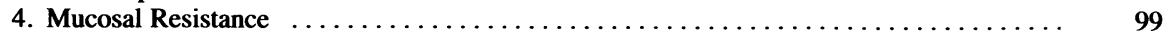

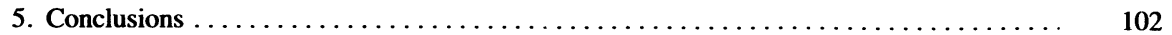

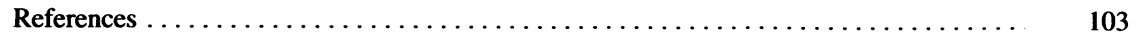

\section{CHAPTER 7: Malabsorption Syndromes}

HENRIK WESTERGAARD and JOHN M. DIETSCHY

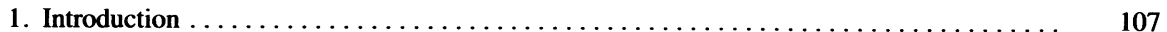

2. Lipid Digestion and Absorption $\ldots \ldots \ldots \ldots \ldots \ldots \ldots \ldots \ldots \ldots \ldots \ldots \ldots \ldots \ldots \ldots \ldots$

3. Normal Enterohepatic Circulation of Bile Acids $\ldots \ldots \ldots \ldots \ldots \ldots \ldots \ldots \ldots \ldots \ldots \ldots \ldots$

4. Carbohydrate and Protein Digestion and Absorption $\ldots \ldots \ldots \ldots \ldots \ldots \ldots \ldots \ldots \ldots \ldots$

5. Tests of Intestinal Digestive and Absorptive Function $\ldots \ldots \ldots \ldots \ldots \ldots \ldots \ldots \ldots \ldots \ldots \ldots$

6. Diseases Affecting Normal Digestion or Absorption $\ldots \ldots \ldots \ldots \ldots \ldots \ldots \ldots \ldots \ldots \ldots$

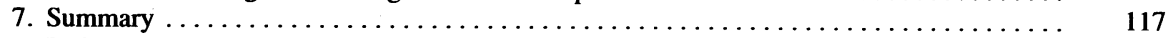

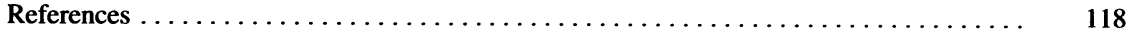

\section{CHAPTER 8: Pathophysiology of Calcium Absorptive Disorders}

STANLEY J. BIRGE and LOUIS V. AVIOLI

1. Introduction $\ldots \ldots \ldots \ldots \ldots \ldots \ldots \ldots \ldots \ldots \ldots \ldots \ldots \ldots \ldots \ldots \ldots \ldots \ldots \ldots \ldots \ldots$

2. Regulation of Intestinal Calcium Absorption $\ldots \ldots \ldots \ldots \ldots \ldots \ldots \ldots \ldots \ldots \ldots \ldots \ldots \ldots \ldots \ldots$

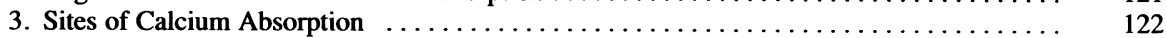

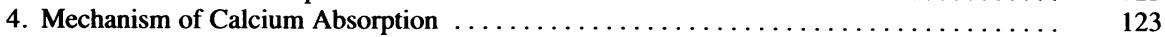

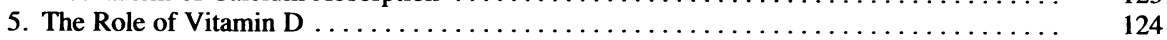

6. Clinical Disorders Associated with Alterations in Calcium Absorption . . . . . . . . . 126

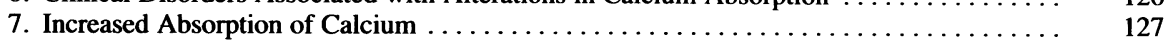

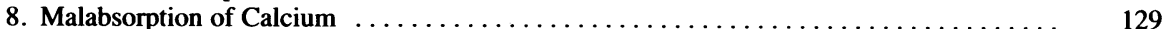

9. Drug-Induced Inhibition of Calcium Absorption $\ldots \ldots \ldots \ldots \ldots \ldots \ldots \ldots \ldots \ldots \ldots \ldots \ldots \ldots \ldots$

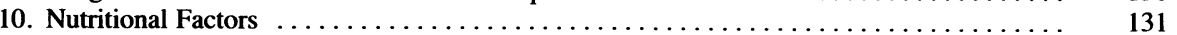

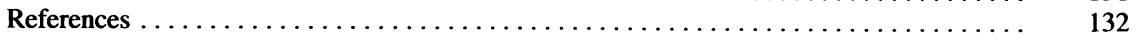

\section{CHAPTER 9: Cystic Fibrosis}

\section{JOHN A. MANGOS}

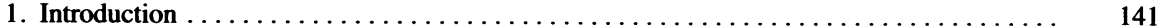

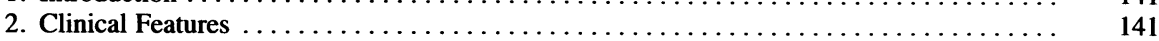

3. Prognosis . . . . . . . . . . . . . . . . . . . . . . . . . . . . . . . 142

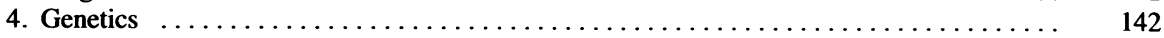

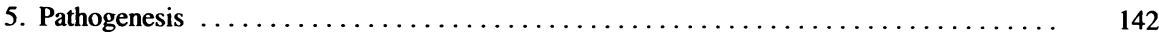

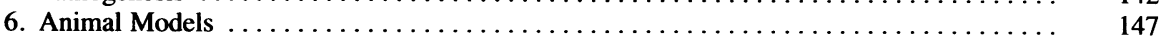

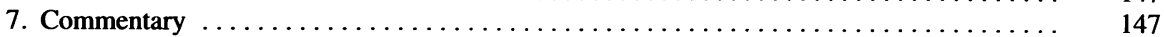

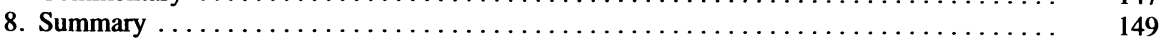

References $\ldots \ldots \ldots \ldots \ldots \ldots \ldots \ldots \ldots \ldots \ldots \ldots \ldots \ldots \ldots \ldots \ldots \ldots \ldots \ldots \ldots \ldots$ 
CHAPTER 10: Disorders of Glomerular Filtration

ROLAND C. BLANTZ and JUAN C. PELAYO

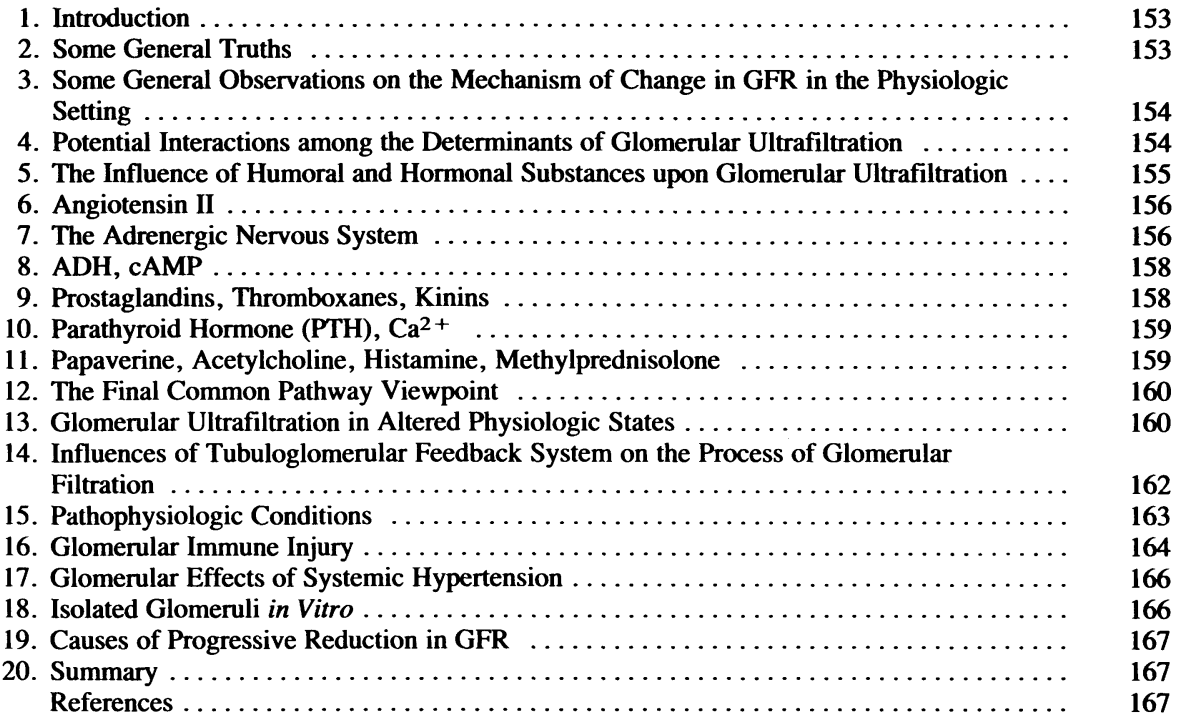

CHAPTER 11: The Hypertonic and Hypotonic Syndromes

R. MICHAEL CULPEPPER, STEVEN C. HEBERT, and THOMAS E. ANDREOLI

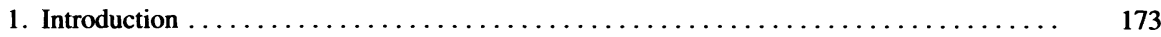

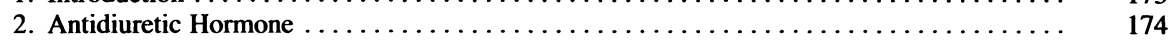

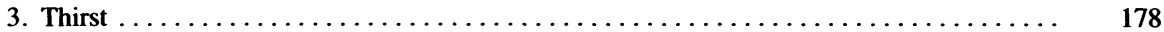

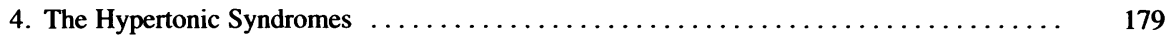

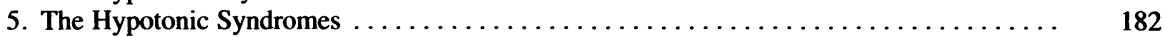

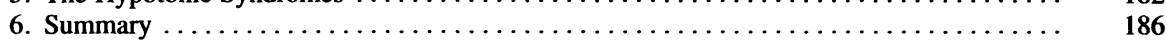

References $\ldots \ldots \ldots \ldots \ldots \ldots \ldots \ldots \ldots \ldots \ldots \ldots \ldots \ldots \ldots \ldots \ldots \ldots$

\section{CHAPTER 12: Disorders of Proton Secretion by the Kidney}

PHILIP R. STEINMETZ and JOSEPH PALMISANO

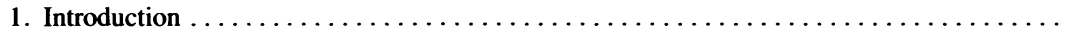

2. Proton Transport across Urinary Epithelia $\ldots \ldots \ldots \ldots \ldots \ldots \ldots \ldots \ldots \ldots \ldots \ldots \ldots \ldots \ldots$

3. Functional Organization of $\mathrm{H}^{+}$Secretion in the Kidney $\ldots \ldots \ldots \ldots \ldots \ldots \ldots \ldots \ldots \ldots$

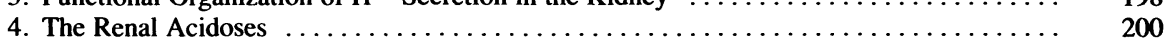

5. Reduced Nephron Population $\ldots \ldots \ldots \ldots \ldots \ldots \ldots \ldots \ldots \ldots \ldots \ldots \ldots \ldots \ldots \ldots \ldots \ldots \ldots . \ldots \ldots$

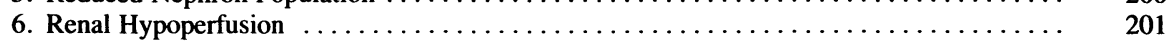

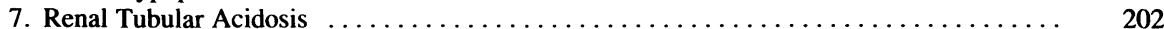

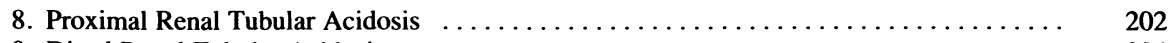

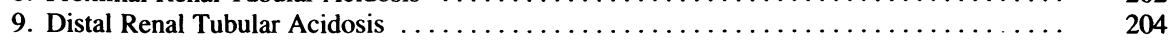

10. Impaired Excretion of Net Acid and Potassium (Normal pH Gradient Formation) . . . . . 209

11. Clinical Aspects of Renal Tubular Acidosis and Associated Disorders of

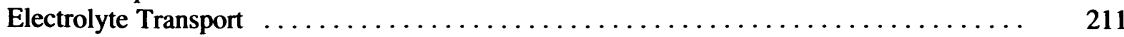

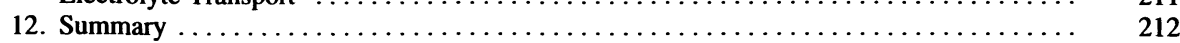

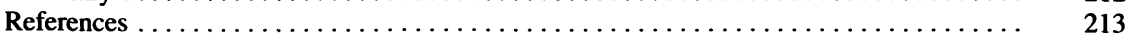

CHAPTER 13: Cystinosis and the Fanconi Syndrome JERRY A. SCHNEIDER and JOSEPH D. SCHULMAN

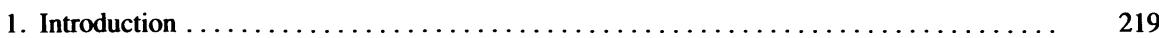

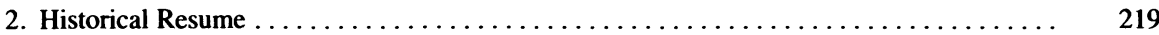

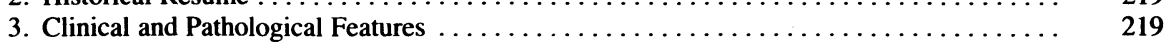

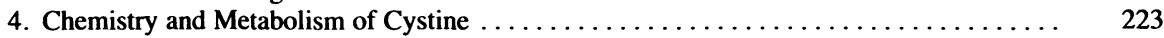




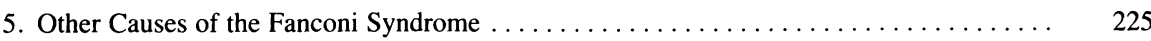

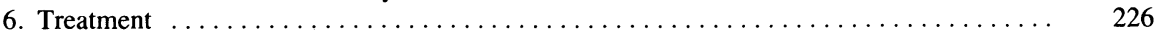

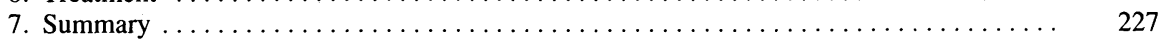

References .......................................... 228

CHAPTER 14: Renal Tubular Defects in Phosphate and Amino Acid Transport RALPH A. DEFRONZO and SAMUEL O. THIER

1. Introduction $\ldots \ldots \ldots \ldots \ldots \ldots \ldots \ldots \ldots \ldots \ldots \ldots \ldots \ldots \ldots \ldots \ldots \ldots \ldots \ldots \ldots \ldots, 233$

2. Defects in Phosphate Transport Processes $\ldots \ldots \ldots \ldots \ldots \ldots \ldots \ldots \ldots \ldots \ldots \ldots \ldots, 233$

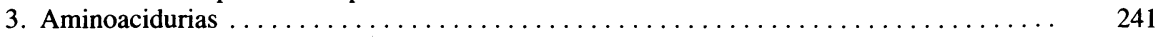

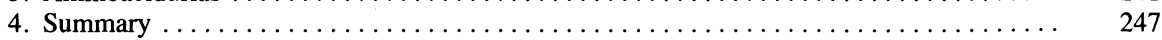

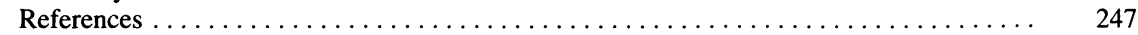

\section{CHAPTER 15: Pulmonary Edema}

AUBREY E. TAYLOR and BENGT RIPPE

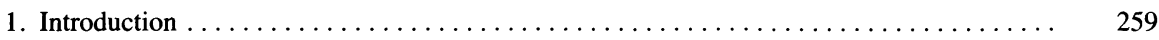

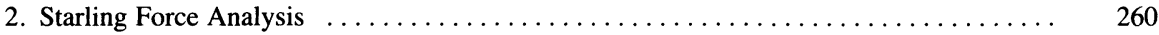

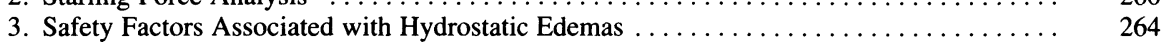

4. Safety Factors Associated with Noncardiac Edema . . . . . . . . . . . . . . . . . 266

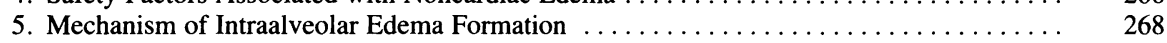

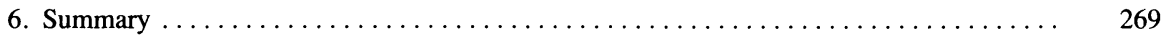

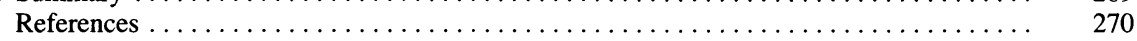

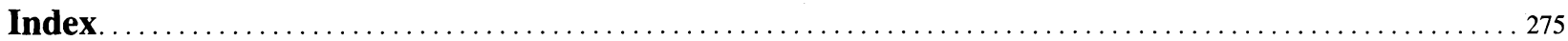




\section{CLINICAL DISORDERS \\ OF MEMBRANE \\ TRANSPORT PROCESSES}

